\section{Australian Journal of \\ Crop Science}

AJCS

ISSN:1835-2707

AJCS 12(12):1806-1812 (2018)

doi: 10.21475/ajcs.18.12.12.p942

\title{
Chlorophyll content, water relation traits and mineral ions accumulation in soybean as influenced by organic amendments under salinity stress
}

\author{
Jannatul Ferdous ${ }^{1}$, M. A. Mannan*2, M. M. Haque ${ }^{2}$, M. A. A Mamun ${ }^{2}$, M. S. Alam ${ }^{3}$ \\ ${ }^{1}$ Bangladesh Jute Research Institute, Dhaka, Bangladesh \\ ${ }^{2}$ Department of Agronomy, Bangabandhu Sheikh Mujibur Rahman Agricultural University, Gazipur-1706, \\ Bangladesh \\ ${ }^{3}$ Department of Soil Science, Bangabandhu Sheikh Mujibur Rahman Agricultural University, Gazipur-1706, \\ Bangladesh
}

\section{*Corresponding author: mannanbsmrau@yahoo.com}

\begin{abstract}
The pot experiment was conducted to assess the effect of organic amendments to improve leaf chlorophyll and water content as well as mineral ions accumulation in BARI soybean 5 under saline condition. Two types of organic amendments $\mathrm{i}$. water hyacinth compost ii. rice husk biochar were mixed in soil at $5 \mathrm{tha}^{-1}$ and 10 tha $^{-1}$ of both. Irrigation was done with 50 and $100 \mathrm{mM}$ saline solution from $14^{\text {th }}$ days after sowing (DAS) to maturity, where control plants were irrigated with tap water. Data on chlorophyll content, exudation rate, relative water content (RWC), water retention capacity (WRC) in leaf were measured at flowering stage as well as $\mathrm{Na}, \mathrm{K}, \mathrm{Ca}, \mathrm{Mg}$ and $\mathrm{Na}$ : $\mathrm{K}$ ratio in leaf and stem were also recorded at harvest. Results revealed that salinity decreased chlorophyll content, exudation rate, relative water content, water retention capacity and $\mathrm{K}, \mathrm{Ca}, \mathrm{Mg}$ content in leaf and stem of soybean plant. Water hyacinth compost and rice husk biochar had positive effects to mitigate negative effects of salinity on soybean plant. However, rice husk biochar at 5 tha $^{-1}$ showed best result to mitigate salinity stress on soybean at low salinity ( 50 $\mathrm{mM}$ ) condition.
\end{abstract}

Keywords: Chlorophyll, mineral ions, organic amendments, salinity, water relations.

Abbreviations: DAS_ days after sowing; RWC_relative water content; WRC_water retention capacity.

Introduction

Agricultural productivity is severely affected by soil salinity and the damaging effect of salt accumulation in agricultural soils has become an important environmental concern all over the world (Jaleel et al., 2007). Salinity drastically affects different physiological processes in plant like water relation traits, chlorophyll degradation; accumulation of organic solutes and other activities includes photosynthesis (Soussi et al., 1998), nitrogen (Cordovilla et al., 1995; Mansour, 2000) and carbon metabolism (Delgado et al., 1994; Soussi et al., 1999). Such physiological changes will result in a decrease in plant growth (Mensah et al., 2006) and consequently in crop yield. Accumulation of excess $\mathrm{Na}$ and $\mathrm{Cl}$ in plant body causes ionic imbalances that may impair the selectivity of root membranes and induce potassium deficiency (Gadallah, 1999). There are evidences that soil amendments with various organic substances such as farmyard manure, poultry manure and mulch can be used for the reduction of toxic effects of salinity in various plant species (Idrees et al., 2004; Abou El-Magd et al., 2008; Leithy et al., 2010; Raafat and Thawrat, 2011). The beneficial influence of compost on soil physical and chemical properties has been well documented (Debosz et al., 2002; Lynch et al., 2005; Tejada et al., 2006; Wanas and Omran, 2006). Biochar is pyrolysed organic material intended for use as a soil amendment to sustainably sequester $C$ and concurrently improve soil function, while avoiding any adverse effects, on both the short and long terms (Lehmann and Joseph, 2009; Verheijen et al., 2009). Biochar enhanced soil water-holding capacity (Asai et al., 2009; Laird et al., 2010); improved soil water permeability (Asaie t al., 2009); improved saturated hydraulic conductivity (SHC) (Asai et al., 2009); reduced soil strength (Chan et al., 2007, 2008) and modification in soil bulk density ( $\rho b)$ (Laird et al., 2010). Dramatic improvement of soil chemical properties has been reported with biochar applications to agronomic soils (Chan et al., 2007; Laird et al., 2010). However, role of organic amendments to mitigate salinity effect on plant physiology is not clearly understood. The aim of this research work was to find out the effect of water hyacinth compost and rice husk biochar on some physiological parameters related to salinity tolerance in soybean plants under salt stress.

\section{Results and Discussion}

\section{Leaf Chlorophyll Content}

Organic amendment significantly increased chlorophylla in soybean leaf under control and saline conditions (Table 1). Highest chlorophyll a ( $\left.3.21 \mathrm{mg} \mathrm{g}^{-1}\right)$ was found in plant where biochar was added at $5 \mathrm{t} \mathrm{ha}^{-1}$ and it was $2.72 \mathrm{mg} \mathrm{g}^{-1}$ when compost was added at $5 \mathrm{t} \mathrm{ha}^{-1}$ under control condition. At 50 $\mathrm{mM}$ saline condition highest chlorophyll a $\left(2.43 \mathrm{mg} \mathrm{g}^{-1}\right)$ was 
obtained from biochar at $5 \mathrm{t} \mathrm{ha}^{-1}$ and it was lowest $(2.15 \mathrm{mg}$ $\mathrm{g}^{-1}$ ) when biochar was applied at $10 \mathrm{t} \mathrm{ha}^{-1}$. At $100 \mathrm{mM}$ saline condition highest total chlorophyll (1.86 $\mathrm{mg} \mathrm{g}^{-1}$ ) was obtained when soil was treated with compost at $5 \mathrm{t} \mathrm{ha}^{-1}$ and it was lowest $\left(1.48 \mathrm{mg} \mathrm{g}^{-1}\right)$ when biochar was added in the soil at $10 \mathrm{t} \mathrm{ha}^{-1}$. Increasing salinity concentration in the rooting medium significantly reduced the chlorophyll a, chlorophyll b, and total chlorophyll reported by Ashraf et al. (1989). Chlorophyll b content of soybean plant also was reduced significantly at saline conditions (Table 1). It was significantly lowest at $100 \mathrm{mM}$ salt level than control. Organic amendment significantly increased chlorophyll b of soybean plant under control and saline conditions. Highest chlorophyll b (1.91 $\mathrm{mg} \mathrm{g}^{-1}$ ) was observed when compost was added at $5 \mathrm{t} \mathrm{ha}^{-1}$ and it was $1.57 \mathrm{mg} \mathrm{g}^{-1}$ when biochar was added at $5 \mathrm{t} \mathrm{ha}^{-1}$ under control condition. At $50 \mathrm{mM}$ salinity condition, highest chlorophyll b $\left(1.59 \mathrm{mg} \mathrm{g}^{-1}\right)$ was obtained from biochar at $10 \mathrm{t} \mathrm{ha}^{-1}$ and lowest chlorophyll b $(1.23 \mathrm{mg}$ $\mathrm{g}^{-1}$ ) was observed when biochar was applied at $5 \mathrm{t} \mathrm{ha}^{-1}$. Under $100 \mathrm{mM}$ saline condition highest chlorophyll b content $\left(1.04 \mathrm{mg} \mathrm{g}^{-1}\right)$ was obtained when soil was treated with compost at $10 \mathrm{t} \mathrm{ha}^{-1}$ and it was lowest $\left(0.63 \mathrm{mg} \mathrm{g}^{-1}\right)$ when compost was added in the soil at $5 \mathrm{t} \mathrm{ha}^{-1}$. Both chlorophyll a and chlorophyll $b$ decreased with increasing salinity. Our findings are in line with the findings of Hajer et al. (2006). Total chlorophyll of leaf in soybean plant also was reduced significantly at salinity conditions. Organic amendment significantly increased total chlorophyll of soybean under control and saline conditions. Highest total chlorophyll (4.79 $\mathrm{mg} \mathrm{g}^{-1}$ ) was observed when biochar was added at $5 \mathrm{t} \mathrm{ha}^{-1}$ and the lowest was $4.53 \mathrm{mg} \mathrm{g}^{-1}$ when compost was added at $10 \mathrm{t} \mathrm{ha}^{-1}$ under control condition. At $50 \mathrm{mM}$ salinity condition, highest total chlorophyll $(3.81 \mathrm{mg}$ $\mathrm{g}^{-1}$ ) was obtained from compost at $5 \mathrm{t} \mathrm{ha}^{-1}$ and lowest total chlorophyll (3.67 $\mathrm{mg} \mathrm{g}^{-1}$ ) was observed when biochar was applied at $5 \mathrm{t} \mathrm{ha}^{-1}$. At $100 \mathrm{mM}$ saline condition, highest total chlorophyll $\left(2.65 \mathrm{mg} \mathrm{g}^{-1}\right)$ was obtained when soil was treated with compost at $10 \mathrm{t} \mathrm{ha}^{-1}$ and it was lowest $\left(2.38 \mathrm{mg} \mathrm{g}^{-1}\right)$ when biochar was added in the soil at $10 \mathrm{t} \mathrm{ha}^{-1}$. When plants are grown under saline conditions, photosynthetic activity was decreases leading to reduced chlorophyll content and chlorophyll fluorescence reported by Muhammad et al. (2007). Ali et al. (2004) also showed that the chlorophyll concentrations were reduced by salinity. Plants grown under salinity without biochar amendment showed $9.7 \%, 17 \%$ and $30 \%$ reduction in total chlorophyll content compared to respective control. Results indicate that chlorophyll content was improved by biochar application under salinity stress. Under the normal condition, $4 \%$ increase in total chlorophyll content was observed by $2 \%$ biochar, while $7 \%$ increase at $1 \%$ biochar. Under stress of $150 \mathrm{mM}$ solution of $\mathrm{NaCl}$, the application of $2 \%$ biochar showed an increase of $20 \%$, while $1 \%$ biochar showed an increase of $13 \%$. (Kanwal et al., 2017). Considerable increase in chlorophyll content was observed due to biochar amendment across all treatments. According to Akhtar, Andersen, and Liu (2015b), the application of biochar elevates photosynthesis rate, which is an indication of increased chlorophyll content.

\section{Exudation rate}

Salinity decreased the exudation rate drastically in soybean plant and decreasing rate was higher with increasing salinity levels (Fig. 1). The lowest exudation rate $\left(178 \mathrm{mg} \mathrm{h}^{-1}\right)$ was found at $100 \mathrm{mM}$ salt stress level when no organic amendment was applied in the soil. Compost and biochar amendments increased the exudation rate of soybean plant both in control and saline conditions. At control condition highest exudation rate $\left(903 \mathrm{mg} \mathrm{h}^{-1}\right)$ was observed when biochar was added in the soil at $5 \mathrm{t} \mathrm{ha}^{-1}$ and it was lowest $\left(659 \mathrm{~m} \mathrm{~h}^{-1}\right)$ when soil was treated with compost at $5 \mathrm{t} \mathrm{ha}^{-1}$. At $50 \mathrm{mM}$ salinity stress highest exudation was $458 \mathrm{mg} \mathrm{h}^{-1}$ when compost was added at $5 \mathrm{t} \mathrm{ha}^{-1}$. On the other hand lowest exudation was $417 \mathrm{mg} \mathrm{h}^{-1}$ when soil was treated with biochar at $5 \mathrm{t} \mathrm{ha}^{-1}$. At $100 \mathrm{mM}$ salinity maximum exudation (332 $\mathrm{mg} \mathrm{h}^{-1} \mathrm{mg} / \mathrm{h}$ ) was observed in the treatment when biochar was added at $5 \mathrm{tha}^{-1}$ and it was minimum $\left(284 \mathrm{mg} \mathrm{h}^{-}\right.$ $\left.{ }^{1}\right)$ when soil water hyacinth compost was added at $5 \mathrm{t} \mathrm{ha}^{-1}$ in the soil. In a study, there was clear evidence of amendment soil interaction processes affecting both soil properties and exudation rate particularly for biochar that might lead to greater changes with additional field emplacement time reported by Akhter et al. (2015). Salinity induced reduction of xylem exudation rate was also observed by Pessarakli and Kabir et al. (2005).

\section{Relative water content}

RWC was decreasing with increasing salinity levels (Fig. 2). The control treatment showed $89 \%$ RWC and it reduced to $73 \%$ at $100 \mathrm{mM}$ salinity level. Organic amendment significantly increased RWC of soybean under control and saline conditions. Highest RWC (93.67\%) was observed when biochar was added at $5 \mathrm{t} \mathrm{ha}^{-1}$ and lowest RWC (88.67\%) was when biochar was added at $10 \mathrm{t} \mathrm{ha}^{-1}$ under control condition. At $50 \mathrm{mM}$ salinity condition, highest RWC (88\%) was obtained from compost at $5 \mathrm{t} \mathrm{ha}^{-1}$ and lowest RWC (84\%) was observed, when biochar was applied at $5 \mathrm{t} \mathrm{ha}^{-1}$. Under $100 \mathrm{mM}$ saline condition highest RWC (78.33\%) was obtained when soil was treated with compost at $5 \mathrm{t} \mathrm{ha}^{-1}$ and it was lowest (76.33\%) when biochar was added in the soil at $5 \mathrm{t} \mathrm{ha}^{-1}$. Salinity induced decrease of RWC was also reported by, Nandwal et al. (2000) and Stoyanov (2005) in young bean, Kabir et al. (2005) in mungbean. These findings also correlate with the study of Akhtar et al. (2015), where adverse effects of salinity on the midday water potential of plants were determined, but biochar amendment played its role in overcoming the negative effect of stress on leaf water potential.

\section{Water retention capacity}

Salinity decreased the water retention capacity (WRC) significantly in soybean plant and the decreasing rate was higher with increasing salinity levels (Fig. 3). Organic amendments significantly increase WRC of soybean among at $5 \mathrm{tha}^{-1}$ and at $10 \mathrm{t} \mathrm{ha}^{-1}$ compost and biochar treatment at $0 \mathrm{mM}, 50 \mathrm{mM}$ and $100 \mathrm{mM}$ salinity levels. In case of biochar, WRC were significantly increased by biochar treatment at every salinity level. Highest WRC (8.2) was observed when biochar was added at 5 tha ${ }^{-1}$ and it was 7.6 when biochar was added at $10 \mathrm{t} \mathrm{ha}^{-1}$ under control condition. At $50 \mathrm{mM}$ salinity condition highest WRC (6.5) was obtained from biochar at $5 \mathrm{t} / \mathrm{ha}$ and lowest WRC (5.4) was observed when compost was applied at $5 \mathrm{t} \mathrm{ha}^{-1}$. Under $100 \mathrm{mM}$ saline condition highest WRC (4.4) was obtained when soil was treated with compost at $5 \mathrm{t} \mathrm{ha}^{-1}$ and it was lowest (3.8) when biochar was added in the soil at $10 \mathrm{t} \mathrm{ha}^{-1}$. Organic 
amendments like compost has beneficial effects on

reclamation of saline soils through improvement of soil

Table 1.Effect of organic amendments on chlorophyll $a$, chlorophyll $b$ and total chlorophyll of soybean leaf under saline conditions.

\begin{tabular}{|c|c|c|c|}
\hline Treatments & Chlorophyll a ( $\mathrm{mg} \mathrm{g}^{-1}$ fresh wt.) & Chlorophyll b ( $\mathrm{mg} \mathrm{g}^{-1}$ fresh wt.) & Total chlorophyll (mg g ${ }^{-1}$ fresh wt.) \\
\hline Control & $2.54 \mathrm{~cd}$ & $1.85 \mathrm{ab}$ & $4.39 \mathrm{c}$ \\
\hline $50 \mathrm{mM}$ sea water & $1.81 \mathrm{gh}$ & $1.80 \mathrm{abc}$ & $3.61 \mathrm{dfg}$ \\
\hline $100 \mathrm{mM}$ sea water & $1.27 \mathrm{k}$ & $1.01 \mathrm{fg}$ & $2.28 \mathrm{~h}$ \\
\hline Control $\times 5$ tha $^{-1}$ compost & $2.72 \mathrm{c}$ & $1.91 \mathrm{a}$ & $4.63 \mathrm{ab}$ \\
\hline Control $\times 10$ tha $^{-1}$ compost & $2.94 \mathrm{~b}$ & $1.59 a b c$ & $4.53 \mathrm{bc}$ \\
\hline $50 \mathrm{mM}$ sea water $\times 5$ tha ${ }^{-1}$ compost & 2.33 ef & $1.48 \mathrm{~cd}$ & $3.81 \mathrm{~d}$ \\
\hline $50 \mathrm{mM}$ sea water $x 10$ tha $^{-1}$ compost & 2.26 ef & $1.53 \mathrm{bcd}$ & $3.79 \mathrm{~d}$ \\
\hline $100 \mathrm{mM}$ sea water $\times 5$ tha $^{-1}$ compost & $1.86 \mathrm{~g}$ & $0.63 \mathrm{~h}$ & $2.49 \mathrm{fgh}$ \\
\hline $100 \mathrm{mM}$ sea water $\times 10$ tha $^{-1}$ compost & $1.61 \mathrm{hi}$ & $1.04 \mathrm{fg}$ & $2.65 \mathrm{dfg}$ \\
\hline Control $\times 5$ tha $^{-1}$ rice biochar & $3.21 \mathrm{a}$ & $1.57 \mathrm{bc}$ & $4.79 \mathrm{a}$ \\
\hline Control $\times 10$ tha $^{-1}$ rice biochar & $2.99 \mathrm{~b}$ & $1.73 a b c$ & $4.72 \mathrm{ab}$ \\
\hline $50 \mathrm{mM}$ sea water $\times 5$ tha $^{-1}$ rice biochar & $2.43 \mathrm{de}$ & $1.23 \mathrm{df}$ & $3.67 \mathrm{df}$ \\
\hline $50 \mathrm{mM}$ sea water $\times 10$ tha ${ }^{-1}$ rice biochar & $2.15 \mathrm{f}$ & $1.59 a b c$ & $3.74 \mathrm{~d}$ \\
\hline $100 \mathrm{mM}$ sea water $\times 5$ tha $^{-1}$ rice biochar & $1.58 \mathrm{ij}$ & $1.00 \mathrm{fg}$ & $2.59 \mathrm{dfg}$ \\
\hline $100 \mathrm{mM}$ sea water $x 10$ tha $^{-1}$ rice biochar & $1.48 \mathrm{ij}$ & $0.90 \mathrm{gh}$ & $2.38 \mathrm{gh}$ \\
\hline $\mathrm{CV}(\%)$ & 5.5 & 14.1 & 3.8 \\
\hline
\end{tabular}

(Figures having similar letters did not vary significantly)

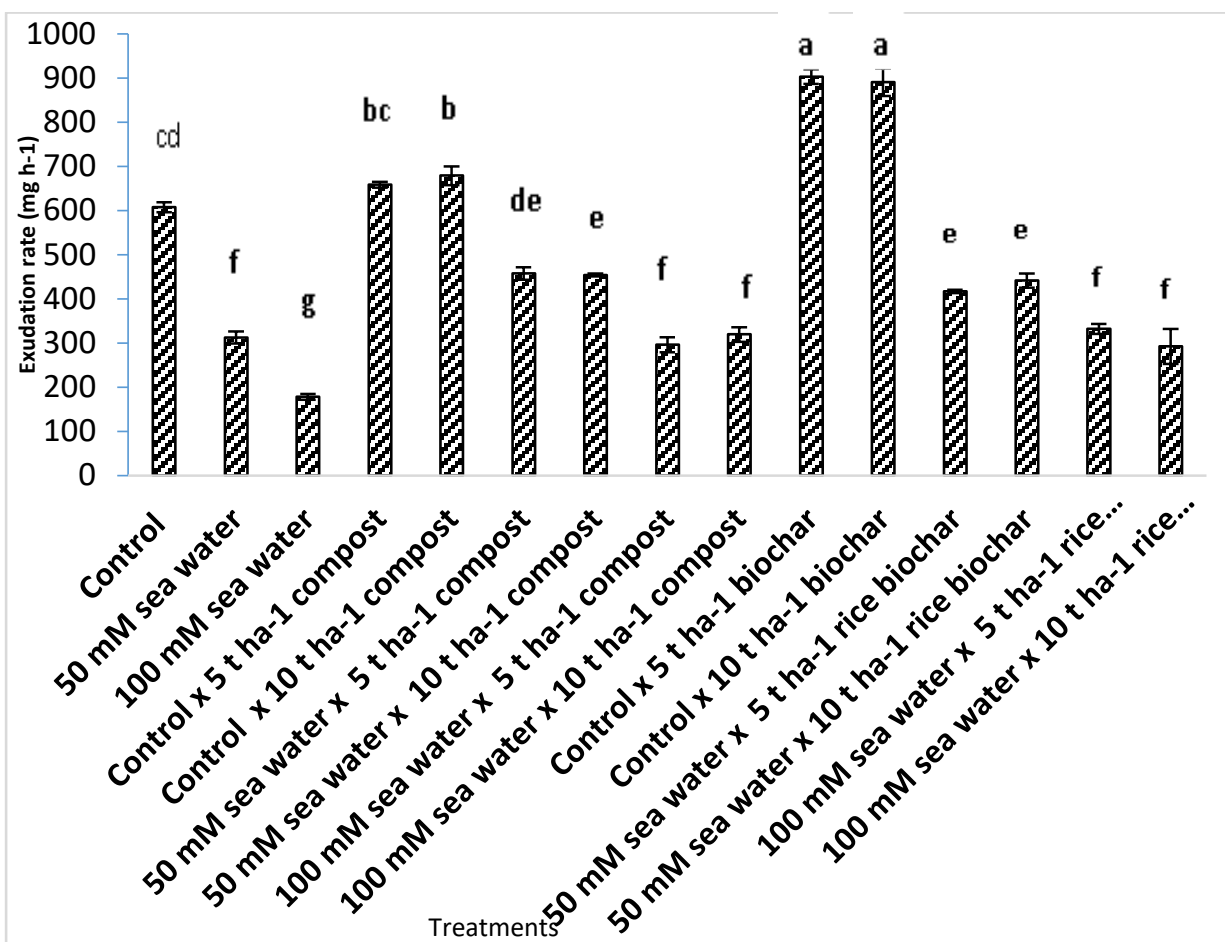

Fig 1. Effect of organic amendments on exudation rate under saline conditions. Bars indicate SE ( \pm ). (Figures having similar letters did not vary significantly).

Table 2. Effect of organic amendments on concentration of $\mathrm{Na}, \mathrm{K}, \mathrm{Ca}, \mathrm{Mg}$ and $\mathrm{Na}$ : $\mathrm{K}$ ratio in leaf of soybean under saline conditions.

\begin{tabular}{|c|c|c|c|c|c|}
\hline Treatments & $\mathrm{Na}(\%)$ & $\mathrm{K}(\%)$ & $\mathrm{Ca}(\%)$ & $\mathrm{Mg}(\%)$ & $\mathrm{Na}: \mathrm{K}$ ratio \\
\hline Control & 0.71 & $1.03 \mathrm{ab}$ & $1.15 \mathrm{fg}$ & 0.54 & $0.68 \mathrm{bc}$ \\
\hline $50 \mathrm{mM}$ sea water & 0.83 & $0.73 a b$ & $1.07 \mathrm{gh}$ & 0.50 & $1.14 \mathrm{ab}$ \\
\hline $100 \mathrm{mM}$ sea water & 0.90 & $0.62 \mathrm{a}$ & $0.86 \mathrm{i}$ & 0.40 & $1.44 \mathrm{a}$ \\
\hline Control $\times 5$ tha $^{-1}$ compost & 0.69 & $1.09 a b$ & $2.07 \mathrm{c}$ & 0.58 & $0.63 \mathrm{bc}$ \\
\hline Control $\times 10$ tha $^{-1}$ compost & 0.67 & $1.08 \mathrm{ab}$ & $2.27 \mathrm{~b}$ & 0.58 & $0.62 \mathrm{bc}$ \\
\hline $50 \mathrm{mM}$ sea water $\times 5$ tha $^{-1}$ compost & 0.78 & $0.83 a b$ & $1.43 \mathrm{e}$ & 0.54 & $0.94 \mathrm{abc}$ \\
\hline $50 \mathrm{mM}$ sea water $\times 10$ tha $^{-1}$ compost & 0.75 & $0.82 \mathrm{ab}$ & $1.27 \mathrm{f}$ & 0.52 & $0.91 \mathrm{abc}$ \\
\hline $100 \mathrm{mM}$ sea water $\times 5$ tha $^{-1}$ compost & 0.82 & $0.76 a b$ & $1.06 \mathrm{gh}$ & 0.44 & $1.07 \mathrm{abc}$ \\
\hline $100 \mathrm{mM}$ sea water $\times 10$ tha $^{-1}$ compost & 0.81 & $0.78 \mathrm{ab}$ & $0.95 \mathrm{hi}$ & 0.47 & $1.04 \mathrm{abc}$ \\
\hline Control $\times 5$ tha $^{-1}$ rice biochar & 0.63 & $1.29 \mathrm{a}$ & $2.43 \mathrm{a}$ & 0.67 & $0.48 \mathrm{c}$ \\
\hline Control $\times 10$ tha $^{-1}$ rice biochar & 0.66 & $1.16 \mathrm{ab}$ & $2.23 \mathrm{~b}$ & 0.63 & $0.57 \mathrm{bc}$ \\
\hline $50 \mathrm{mM}$ sea water $\times 5$ tha $^{-1}$ rice biochar & 0.75 & $1.11 \mathrm{ab}$ & $1.63 \mathrm{~d}$ & 0.59 & $0.68 \mathrm{bc}$ \\
\hline $50 \mathrm{mM}$ sea water $\times 10$ tha $^{-1}$ rice biochar & 0.79 & $1.09 \mathrm{ab}$ & $1.70 \mathrm{~d}$ & 0.57 & $0.73 \mathrm{bc}$ \\
\hline $100 \mathrm{mM}$ sea water $\times 5$ tha $^{-1}$ rice biochar & 0.83 & $0.91 \mathrm{ab}$ & $1.07 \mathrm{gh}$ & 0.44 & $0.91 \mathrm{abc}$ \\
\hline $100 \mathrm{mM}$ sea water $\times 10$ tha $^{-1}$ rice biochar & 0.84 & $0.85 \mathrm{ab}$ & $1.06 \mathrm{gh}$ & 0.48 & $0.99 a b c$ \\
\hline
\end{tabular}




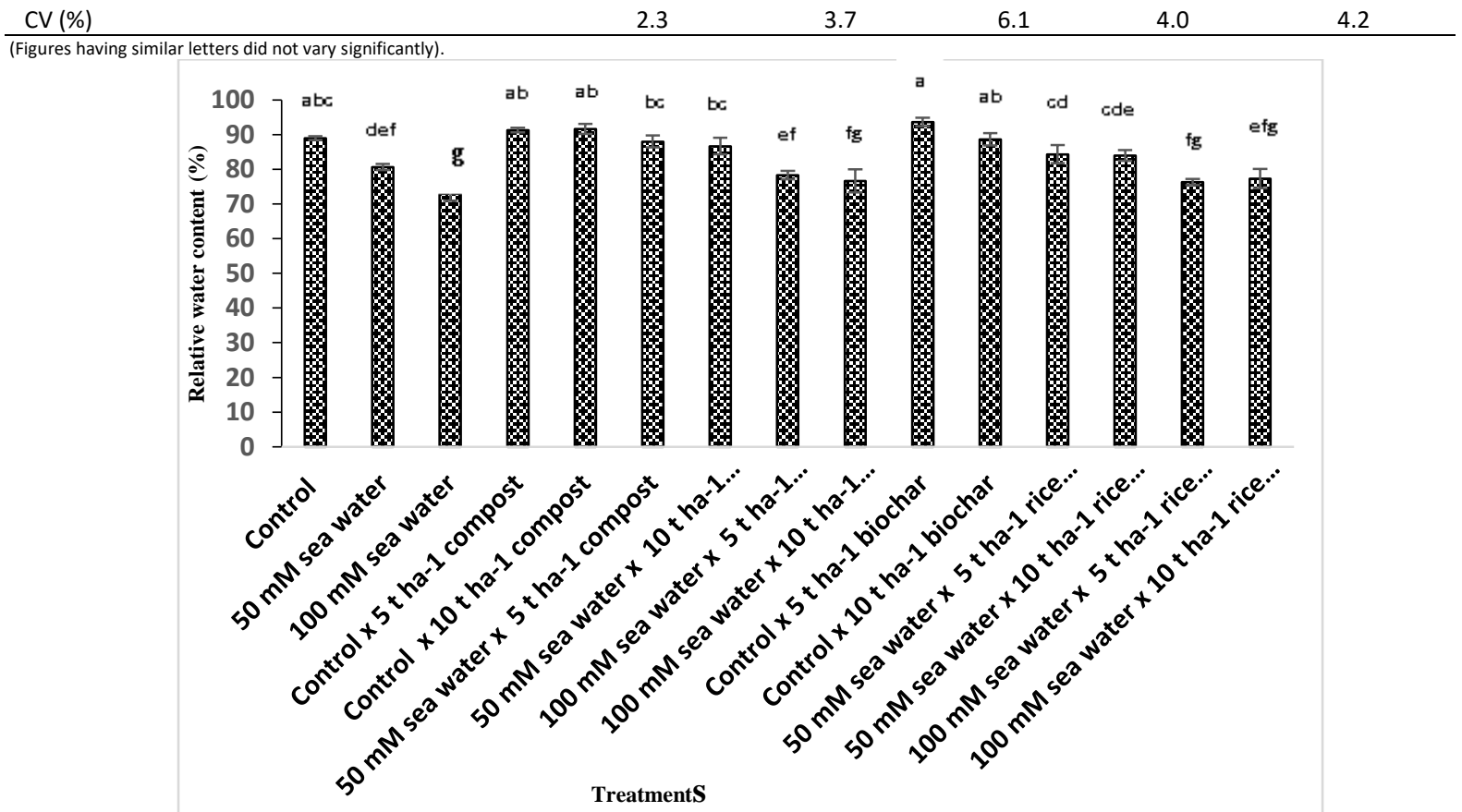

Fig 2. Effect of organic amendments on relative water content under saline conditions. Bars indicate SE ( \pm ). (Figures having similar letters did not vary significantly).

Table 3.Effect of organic amendments on concentration of $\mathrm{Na}, \mathrm{K}, \mathrm{Ca}, \mathrm{Mg}$ and $\mathrm{Na}$ : $\mathrm{K}$ ratio in stem of soybean under saline conditions.

\begin{tabular}{|c|c|c|c|c|c|}
\hline Treatments & $\mathrm{Na}(\%)$ & $\mathrm{K}(\%)$ & $\mathrm{Ca}(\%)$ & $\mathrm{Mg}(\%)$ & Na:K ratio \\
\hline Control & $0.67 \mathrm{~b}$ & 1.11 & 0.69 bcde & $0.43 c$ & 0.60 \\
\hline $50 \mathrm{mM}$ sea water & $0.89 a b$ & 0.99 & 0.63 cde & $0.41 \mathrm{c}$ & 0.91 \\
\hline $100 \mathrm{mM}$ sea water & $1.06 \mathrm{a}$ & 0.84 & $0.38 \mathrm{e}$ & $0.37 c$ & 1.28 \\
\hline Control $\times 5$ tha $^{-1}$ compost & $0.64 \mathrm{~b}$ & 1.14 & $0.90 \mathrm{abc}$ & $0.46 \mathrm{c}$ & 0.57 \\
\hline Control $\times 10$ tha $^{-1}$ compost & $0.67 \mathrm{~b}$ & 1.05 & $0.86 \mathrm{abcd}$ & $0.57 \mathrm{abc}$ & 0.64 \\
\hline $50 \mathrm{mM}$ sea water $\times 5$ tha $^{-1}$ compost & $0.76 a b$ & 0.98 & $0.82 \mathrm{abcd}$ & $0.56 \mathrm{abc}$ & 0.79 \\
\hline $50 \mathrm{mM}$ sea water $\times 10$ tha $^{-1}$ compost & $0.75 a b$ & 1.06 & 0.71 bcde & $0.55 \mathrm{abc}$ & 0.71 \\
\hline $100 \mathrm{mM}$ sea water $\times 5$ tha $^{-1}$ compost & $0.95 \mathrm{ab}$ & 0.92 & $0.45 \mathrm{e}$ & $0.53 \mathrm{bc}$ & 1.03 \\
\hline $100 \mathrm{mM}$ sea water $\times 10$ tha $^{-1}$ compost & $0.97 a b$ & 0.91 & $0.44 \mathrm{e}$ & $0.48 \mathrm{bc}$ & 1.07 \\
\hline Control $\times 5$ tha $^{-1}$ rice biochar & $0.60 \mathrm{~b}$ & 1.24 & $1.07 \mathrm{a}$ & $0.86 \mathrm{a}$ & 0.48 \\
\hline Control $\times 10$ tha $^{-1}$ rice biochar & $0.62 \mathrm{~b}$ & 1.19 & $0.99 \mathrm{ab}$ & $0.79 \mathrm{ab}$ & 0.52 \\
\hline $50 \mathrm{mM}$ sea water $\times 5$ tha $^{-1}$ rice biochar & $0.82 a b$ & 1.15 & $0.87 \mathrm{abcd}$ & $0.62 \mathrm{abc}$ & 0.71 \\
\hline $50 \mathrm{mM}$ sea water $\times 10$ tha $^{-1}$ rice biochar & $0.87 \mathrm{ab}$ & 1.06 & $0.92 a b c$ & $0.59 \mathrm{abc}$ & 0.82 \\
\hline $100 \mathrm{mM}$ sea water $\times 5$ tha $^{-1}$ rice biochar & $0.93 \mathrm{ab}$ & 1.0 & $0.46 \mathrm{e}$ & $0.42 c$ & 0.93 \\
\hline $100 \mathrm{mM}$ sea water $\times 10$ tha $^{-1}$ rice biochar & $0.86 a b$ & 0.96 & $0.55 \mathrm{de}$ & $0.45 c$ & 0.90 \\
\hline CV (\%) & 2.9 & 4.1 & 2.9 & 3.6 & 5.6 \\
\hline
\end{tabular}

(Figures having similar letters did not vary significantly)

structure and permeability thus enhancing salt leaching, reducing surface evaporation, and inhibiting salt accumulation in surface soils (Raychev et al., 2001). The impact of biochar on soil WRC was most likely related to an effect in overall porosity of the sandy loam soil, which was evident from an increase in saturated soil moisture and macro porosity with 0.5 and $1.6 \%$ for each $\mathrm{Mgha}^{-1}$ of biochar applied, respectively observed by Carvalho et al. (2014). Biochar can improve plant productivity directly as a result of its nutrient content and release characteristics, as well as indirectly, via: improved soil physical properties (Chan et al., 2008), including an increase in soil water retention (Laird et al., 2010). Increasing the water-holding capacity of sandy soils will help improve efficiency of water use in agricultural production, and may be critical for providing enough energy and food for an increasing global population. Biochar added to sandy loam soil increases water-holding capacity and might increase water available for crop use. (Basso et al., 2012).The application of biochar in soil enhances plant growth by improving water retention, soil organic carbon, and nutrient availability via increasing root density (Kappler et al., 2014; Ramzani et al., 2016a).

\section{Concentration of $\mathrm{Na}, \mathrm{K}, \mathrm{Ca}, \mathrm{Mg}$ and $\mathrm{Na}$ : $\mathrm{K}$ ratio in leaf}

Salinity significantly increases the concentration of $\mathrm{Na}$ and $\mathrm{Na}$ : $\mathrm{K}$ ratio in leaf of the soybean, while that of $\mathrm{K}$ and $\mathrm{Ca}$ decreased with increasing salinity levels.Organic amendments with both compost and biochar significantly decreased $\mathrm{Na}$ and $\mathrm{Na}$ : $\mathrm{K}$ ratio of soybean as well as increased the $\mathrm{K}, \mathrm{Ca}$, and $\mathrm{Mg}$ in leaf of soybean plant at $\mathrm{OmM}, 50 \mathrm{mM}$ and $100 \mathrm{mM}$ salinity stress conditions. At control condition, the lowest $\mathrm{Na}(0.63 \%)$ was found when soil was treated with biochar at 5 tha $^{-1}$ and the highest rate $(0.69 \%)$ was obtained when compost was added in the soil at 5 tha $^{-1}$ and the lowest $\mathrm{Na}$ : K (0.48) ratio was found when soil was treated with biochar at 5 tha $^{-1}$ and the highest rate was (0.63) observed when compost was added in the soil at 5 tha $^{-1}$. At $50 \mathrm{mM}$ salt condition, lowest $\mathrm{Na}(0.75 \%)$ was found when soil was treated with biochar at 5 tha $^{-1}$ as well as compost at $10 \mathrm{t} / \mathrm{ha}$ and the highest rate was $(0.79 \%)$ obtained when 
biochar was added in the soil at $10 \mathrm{t} / \mathrm{ha}$ and lowest $\mathrm{Na:} \mathrm{K}$

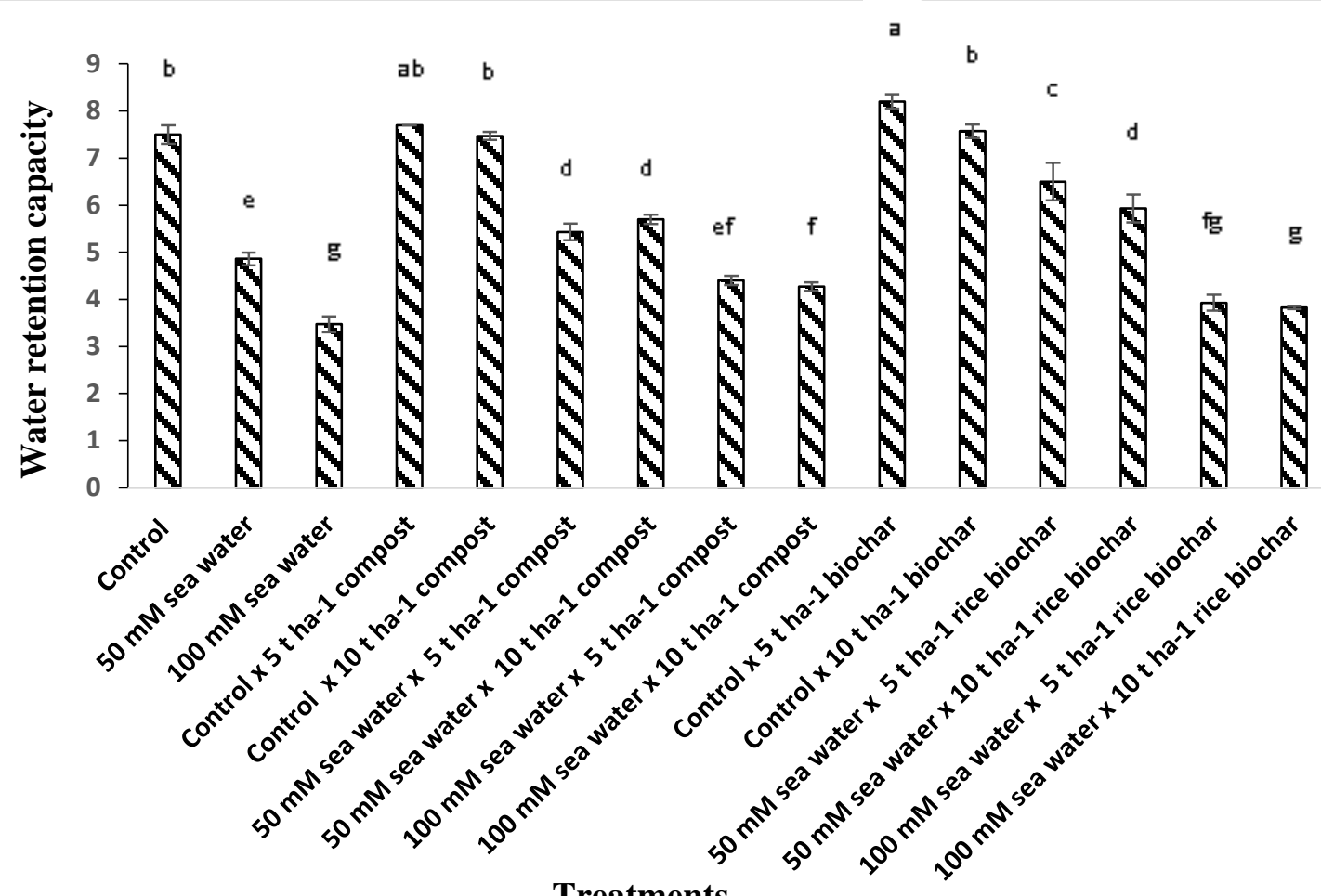

Treatments

Fig 3. Effect of organic amendments on water retention capacity under saline conditions. Bars indicate SE ( \pm ). (Figures having similar letters did not vary significantly).

The soil at 5 tha ${ }^{-1}$. On the other hand under $100 \mathrm{mM}$ salinity condition the lowest $\mathrm{Na}(0.81 \%)$ was found when soil was treated with compost at $10 \mathrm{t} / \mathrm{ha}$ and it was highest $(0.84 \%)$ when biochar was added in the soil at $10 \mathrm{t} / \mathrm{ha}$ and lowest $\mathrm{Na}$ : K (0.91) ratio was found when soil was treated with biochar at $5 \mathrm{t} / \mathrm{ha}^{-1}$ and it was highest (1.07) when compost was added in the soil at $5 \mathrm{tha}^{-1}$. Application of $5 \mathrm{t} / \mathrm{ha}^{-1}$ biochar performed the best among the organic amendments. At control condition, highest $\mathrm{K}$ (1.29\%), $\mathrm{Ca}(2.43 \%), \mathrm{Mg}(0.67 \%)$ was found when soil was treated with biochar at $5 \mathrm{t} / \mathrm{ha}^{-1}$ and the lowest $\mathrm{K}(1.08 \%), \mathrm{Ca}(2.07 \%)$, $\mathrm{Mg}(0.58 \%)$ when compost was added in the soil at $10 \mathrm{t} / \mathrm{ha}$, $5 \mathrm{t} /$ haand both at 5 tha $^{-1}$ as well as $10 \mathrm{t} /$ ha respectively. At $50 \mathrm{mM}$ salt condition highest $\mathrm{K}(1.11 \%), \mathrm{Ca}(1.7 \%), \mathrm{Mg}$ $(0.59 \%)$ was found when soil was treated with biochar at 5 tha ${ }^{-1}$, at $10 \mathrm{t} / \mathrm{ha} 5 \mathrm{t} / \mathrm{ha}$, respectively, and the lowest $\mathrm{K}$ (0.82\%), Ca (1.27\%), Mg (0.52\%) when compost was added in the soil at $10 \mathrm{t} / \mathrm{ha}$. At $100 \mathrm{mM}$ salt stress condition highest $\mathrm{K}(0.91 \%), \mathrm{Ca}(1.07 \%), \mathrm{Mg}(0.48 \%)$ was found when soil was treated with biochar at 5 tha $^{-1}, 5 \mathrm{t} / \mathrm{ha}$ and $10 \mathrm{t} / \mathrm{ha}$, respectively and the lowest $\mathrm{K}(0.76 \%), \mathrm{Ca}(0.95 \%), \mathrm{Mg}$ $(0.44 \%)$ when compost was added in the soil at 5 tha $^{-1}$, at 10 $\mathrm{t} / \mathrm{ha}$ and $5 \mathrm{t} / \mathrm{ha}$, respectively. The compost and manure increased markedly the shoot growth; this seemed to be related to decreases in the shoot concentrations of $\mathrm{Na}$ and $\mathrm{Cl}$ and increases in $\mathrm{K}$ (Ashraf et al., 2004). Conversely, Leithy et al. (2010) found that organic amendments did not show any changes of nutrient content except $\mathrm{Na}$. Organic manures have been shown to increase $\mathrm{K} / \mathrm{Na}$ ratio in sweet fennel (Abou El-Magdet al., 2008). Biochar can increase nutrient content and improved retention of nutrients (Lehmann et al., 2003; Wardle et al., 1998); Amanullah (2008) showed in rice crop.

\section{Concentration of $\mathrm{Na}, \mathrm{K}, \mathrm{Ca}, \mathrm{Mg}$ and $\mathrm{Na}$ : $\mathrm{K}$ ratio in stem}

There was variation in accumulation of these elements in stem of soybean plant due to different salinity levels (Table 3). The concentration of $\mathrm{Na}$ in stem of the soybean increased, while that of $\mathrm{K}, \mathrm{Ca}$ and $\mathrm{Mg}$ were decreased with increasing salinity levels. Organic amendments with both compost and biochar significantly decrease $\mathrm{Na}$ and $\mathrm{Na}: \mathrm{K}$ ratio of soybean as well as increase the $\mathrm{K}, \mathrm{Ca}, \mathrm{Mg}$ in stem of soybean plant at $0 \mathrm{mM}, 50 \mathrm{mM}$ and $100 \mathrm{mM}$ salinity stress conditions. At control condition lowest $\mathrm{Na}(0.60 \%)$ was found when soil was treated with biochar at 5 tha $^{-1}$ and it was highest $(0.67 \%)$ when compost was added in the soil at $10 \mathrm{t} \mathrm{ha}^{-1}$ and lowest $\mathrm{Na}: \mathrm{K}(0.48)$ ratio was found when soil was treated with biochar at 5 tha $^{-1}$ and it was highest (0.64) when compost was added in the soil at $10 \mathrm{t} \mathrm{ha}^{-1}$. At $50 \mathrm{mM}$ salt condition lowest $\mathrm{Na}(0.75 \%)$ was found when soil was treated with compost at $10 \mathrm{t} \mathrm{ha}^{-1}$ and it was highest $(0.87 \%)$ when biochar was added in the soil at $10 \mathrm{t} \mathrm{ha}^{-1}$ and lowest $\mathrm{Na}$ : K (0.71) ratio was found when soil was treated with biochar at 5 tha $^{-1}$ and it was highest (0.82) when biochar was added in the soil at $10 \mathrm{t} \mathrm{ha}^{-1}$. On the other hand under 100 $\mathrm{mM}$ salinity stress condition, lowest $\mathrm{Na}(0.86 \%)$ was found when soil was treated with biochar at $10 \mathrm{t} \mathrm{ha}^{-1}$ and it was highest $(0.97 \%)$ when compost was added in the soil at $10 \mathrm{t}$ $\mathrm{ha}^{-1}$ and lowest $\mathrm{Na}$ : $\mathrm{K}(0.90)$ ratio was found when soil was 
treated with both biochar at $10 \mathrm{t} \mathrm{ha}^{-1}$ and at $10 \mathrm{t} \mathrm{ha}^{-1}$ compost, whereas, the highest ratio (1.07) was found when compost was added in the soil at $10 \mathrm{t} \mathrm{ha}^{-1}$. At control condition, highest $\mathrm{K}(1.24 \%), \mathrm{Ca}(1.07 \%), \mathrm{Mg}(0.86 \%)$ were found when soil was treated with biochar at $5 \mathrm{t} / \mathrm{ha}^{-1}$ and the lowest $\mathrm{K}(1.05 \%), \mathrm{Ca}(0.86 \%), \mathrm{Mg}(0.46 \%)$ were obtained, when compost was added in the soil ha at $10 \mathrm{t} \mathrm{ha}^{-1} @ 10 \mathrm{t} / \mathrm{ha}$ and at 5 tha $^{-1}$, respectively. At $50 \mathrm{mM}$ salt condition, highest $\mathrm{K}(1.15 \%), \mathrm{Ca}(0.92 \%), \mathrm{Mg}(0.62 \%)$ were found when soil was treated with biochar @ $5 \mathrm{t} / \mathrm{ha}$, at $10 \mathrm{t} \mathrm{ha}{ }^{-1} @ 10 \mathrm{t} / \mathrm{ha}$ and 5 $\mathrm{t} / \mathrm{ha}$, respectively and the lowest $\mathrm{K}(0.98 \%), \mathrm{Ca}(0.71 \%), \mathrm{Mg}$ $(0.55 \%)$ when compost was added in the soil at $5 \mathrm{tha}^{-1}$, at 10 $\mathrm{t} \mathrm{ha} \mathrm{h}^{-1}$ and $10 \mathrm{t} / \mathrm{ha}$, respectively. At $100 \mathrm{mM}$ salt stress condition, highest $\mathrm{K}(1.0 \%), \mathrm{Ca}(0.55 \%), \mathrm{Mg}(0.53 \%)$ was found when soil was treated with biochar at $5 \mathrm{t} / \mathrm{ha}^{-1}$, at $10 \mathrm{t}$ $\mathrm{ha}^{-1}$ and compost at 5 tha $^{-1}$, respectively, and the lowest $\mathrm{K}$ (0.91\%) , Ca (0.44\%)@ 10 t/ha compost and Mg (0.42\%) when biochar was added in the soil at $5 \mathrm{tha}^{-1}$, respectively. Incorporation of organic materials for reducing deleterious effects of saline water was reported by many scientists (Minhas et al., 1995; Choudhary et al., 2002). In relation to the application of compost and its benefits, researchers (Graber et al., 2010, Zhang et al., 2012) confirmed that biochar can be also an important tool to increase $\mathrm{Ca}, \mathrm{K}$ and $\mathrm{Mg}$ in soybean plants. The high $\mathrm{Na}+$ adsorption capacity of biochar has also been recently reported by Thomas et al. (2013). Biochar maintains the nutrient balance in soil solution by releasing mineral nutrients, particularly $\mathrm{K}^{+}, \mathrm{Ca}^{2+}$ and $\mathrm{Mg}^{2+}$, thereby reducing $\mathrm{Na}^{+}$uptake, which ultimately increased the ratio of $\mathrm{K}^{+}$or other cations to $\mathrm{Na}^{+}$(Aktar et al., 2015).

\section{Materials and Methods}

The experiment was carried out at the Department of Agronomy, Bangabandhu Sheikh Mujibur Rahman Agricultural University, Gazipur, Bangladeshfrom November 2015 to March 2016.

\section{Planting material}

BARI cultivar of soybean was tested.

\section{Soil analysis}

The soil was a sandy loam with $\mathrm{pH}(6.93)$, total $\mathrm{N}(0.07 \%)$, available $\mathrm{P}\left(0.08 \mathrm{mg} 100 \mathrm{~g}^{-1}\right)$, exchangeable $\mathrm{K}\left(0.79 \mathrm{cmol}_{\mathrm{c}} \mathrm{kg}^{-1}\right.$ dry soil), available $S(10 \mathrm{ppm})$, organic carbon (0.61\%), CEC $\left(13.05 \mathrm{cmol}_{\mathrm{c}} \mathrm{kg}^{-1}\right.$ dry soil) and ECO.4 dSm${ }^{-1}$.

Treatments: Two organic amendments i. water hyacinth compost ii. rice husk biochar were mixed in soil of pot at $5 \mathrm{t}$ $\mathrm{ha}^{-1}$ and $10 \mathrm{t} \mathrm{ha}^{-1}$ of both. Chemical composition of water hyacinth compost and rice husk biochar are presented in the following table (Shaon, 2016)

\begin{tabular}{l|l|l|l|l|l|l|l|l}
\hline $\begin{array}{l}\text { Organic } \\
\text { amendments }\end{array}$ & $\mathrm{pH}$ & $\mathrm{N} \%$ & $\mathrm{P} \%$ & $\mathrm{~K} \%$ & $\mathrm{Ca} \%$ & $\mathrm{Mg} \%$ & $\mathrm{~S} \%$ & $\begin{array}{l}\mathrm{EC} \\
\mathrm{ms} / \mathrm{cm}\end{array}$ \\
\hline compost & 5.9 & 1.10 & 0.096 & 0.16 & 1.08 & 0.12 & 0.63 & 0.35 \\
\hline Biochar & 7.15 & 2.57 & 0.21 & 0.231 & 1.024 & 0.458 & 0.339 & 1.325 \\
\hline
\end{tabular}

Saline solution was prepared by adding tap water in sea water to make 50 and $100 \mathrm{mM}$ salinity level equivalent to 5 and $10 \mathrm{dSm}^{-1}$, respectively. Sea water was collected from the Bay of Bengal and the concentration was $400 \mathrm{mM}$ equivalent to $40 \mathrm{dS} \mathrm{m} \mathrm{m}^{-1}$. Salt solutions were applied in pots from $14^{\text {th }}$ days after sowing (DAS) to maturity and in control pots tap water was used. The treatment combinations were: i. Control (no amendments and no saline water) ii. $50 \mathrm{mM}$ sea water iii. $100 \mathrm{mM}$ sea water iv. Control $\times 5$ tha $^{-1}$ compost v. Control $\times 10$ tha $^{-1}$ compost vi. $50 \mathrm{mM}$ sea water $\times 5$ tha $^{-1}$ compost vii. $50 \mathrm{mM}$ sea water $\times 10$ tha $^{-1}$ compost viii. $100 \mathrm{mM}$ sea water $\times 5$ tha $^{-1}$ compost ix. $100 \mathrm{mM}$ sea water $\times 10$ tha $^{-1}$ compost $x$. Control $\times 5$ tha $^{-1}$ rice biochar xi. Control $\times 10$ tha ${ }^{1}$ rice biochar xii. $50 \mathrm{mM}$ sea water $\times 5$ tha ${ }^{-1}$ rice biochar xiii. $50 \mathrm{mM}$ sea water $\times 10$ tha $^{-1}$ rice biochar $x i v .100 \mathrm{mM}$ sea water $\times 5$ tha $^{-1}$ rice biochar $x v .100 \mathrm{mM}$ sea water $\times 10$ tha $^{-1}$ rice biochar. The experiment was laid out in CRD with three replications. Data on different physiological parameters like chlorophyll content, exudation rate, relative water content (RWC), water retention capacity (WRC) in leaf were measured at flowering stage as well as $\mathrm{Na}, \mathrm{K}, \mathrm{Ca}, \mathrm{Mg}$ and $\mathrm{Na}$ : $\mathrm{K}$ ratio in leaf and stem were also recorded at harvest.

\section{Statistical analysis}

The recorded data were statistically analyzed by "CROPSTAT 7.2" software to examine the significant variation of the results due to different treatments. The treatment means were compared by Duncan's Multiple Range test (DMRT) at $5 \%$ level of significance (Gomez and Gomez, 1984).

\section{Conclusion}

Salinity decreased chlorophyll content, exudation rate, relative water content, water retention capacity and $\mathrm{K}, \mathrm{Ca}$, $\mathrm{Mg}$ content in leaf and stem of soybean plant. Application of water hyacinth compost and rice husk biochar had positive effects to mitigate negative effects of salinity on physiological parameters studied. However, rice husk biochar at the rate of $5 \mathrm{t} \mathrm{ha}^{-1}$ showed best result to mitigate salinity effects at low salinity $(50 \mathrm{mM})$ condition.

\section{References}

Abou El-Magd MM, Zaki MF, Abou-Hussein SD (2008) Effect of organic manure and different levels of saline irrigation water on growth, green yield and chemical content of sweet fennel. Aust J of Basic and Applied Sci. 2(1): 90-98.

Ahmadullah M, Niazi BH, Sandhu GR (2008) Effectiveness of gypsum, $\mathrm{HCL}$ and organic matter for the improvement of saline sodic soils. Pak J Agric Res. 9(3): 373-378.

Akhtar SS, Mathias NA, Muhammad N, Zahir AZ, Fulai L (2015) Interactive effect of biochar and plant growth-promoting bacterial endophytes on ameliorating salinity stress in maize. Functional PI Biology. 42: 770-781.

Ali MA, Islam MT, Islam MT (2004) Effect of salinity on some morphophysiological characters and yield in three sesame cultivars. J Bangladesh Agric Univ.3: 209-214.

Anjum SA, Xie X, Wang L, Saleem MF, Man C, Lei W (2011) Morphological, physiological and biochemical responses of plants to drought stress. African J Agric Res. 6(9): 2026-2032.

Asai H, Samson BK, Stephan HM, Songyi khangsuthor K, Homma K, Kiyono Y, Inoue Y, Shiraiwa T, Horie T (2009) Biochar amendment techniques for upland rice production in Northern Laos 1. Soil physical properties, leaf SPAD and grain yield. Field Crop Res. 111: 81-84.

Ashraf M, Hasnain S, Berge O, Mahmod T (2004) Inoculating wheat seedlings with exopolysaccharide-producing bacteria restricts sodium uptake and stimulates plant growth under salt stress. Bio Fertility Soil.40: 157-162.

Chan KY, Zwieten LV, Meszaros I, Downie A, Joseph S (2007) Agronomic values of greenwastebiochar as a soil amendment. Aust J Soil Res. 45: 629-634. 
Chan KY, Zwieten LV, Meszaros I, Downie A, Joseph S (2008) Using poultry litter biochars as soil amendments. Aust J Soil Res. 46:437-444.

Choudhary OP, Josan AS, Bajwa MS (2002) Role of organic materials in mobilizing intrinsic calcium carbonate to ameliorate sodic irrigations. In: Proceedings of the 17th World Congress Soc Sci. 34(3): 22-36.

Cordovilla, MP, Ocana A, Ligero F, Lluch C (1995) Growth and macronutrient contents of faba bean plants: Effects salinity and nitrate nutrition. J Plant Nutr. 18:1611-1628.

Debosz K, Petersen SBO, Kure LK, Ambus P (2002) Evaluating effects of sewage sludge and household compost on soil physical, chemical and microbiological properties. Appl Soil Ecol.19: 237-248.

Delgado MJ, Ligero F, Lluch C (1994) Effects of salt stress on growth and nitrogen fixation by pea, faba-bean, common bean and soybean plants. Soil Biol Biochem. 26: 371-376.

Gaballah MS, Mandour MS (1999) Increasing drought resistance of wheat plants during grain filling byusing chemical desiccants. J Sci Mansoura Univ. 25(2): 833-841.

Gomez AA, Gomez AA (1984) Statistical procedure of agricultural Research. John Wiley and Sons. New York.Pp: 202015.

Gopal, Dube KS (2003) Influence of soil and foliar application of potassium on growth, nutrient utilization, yield and quality of sugarcane (Saccharum officinarumL.). New Botanist. 21(1-4): 13-20.

Graber ER, Hare YM, Kolton M, Cytryn E, Silber A, David DR, Tsechansky L, Borenshtein M, Elad Y (2010) Biochar impact on development and productivity of pepper and tomato grown in fertigated soilless media. Plant Soil. 337: 481-496.

Hajer AS, Malibari AA, Al-Zahrani HS, Almaghrabi OA (2006) Responses of three tomato cultivars to sea water salinity 1 . Effect of salinity on the seedling growth. Afri J Biotech. 5 (10): 855-861.

Idrees S, Qureshi MS, Ashraf MY, Hussain Mand Naveed NH (2004) Influence of sulphate of potash (Sop) and farmyard manure (Fym) on sugarcane (Saccharum officinarum L.) grown under salt stress. Pak J Life Social Sci. 2(1): 65-69.

Jaleel CA, Gopi R, Manivannan P, Panneerselvam R (2007) Responses of antioxidant defense system of Catharanthus roseus L. G. Don. To paclobutrazol treatment under salinity. Acta Physiologiae Plantanirn.29: 205-209.

Kabir MF, Hamid A, Haque MM, Nawata E, Karim MA (2005) Effect of nitrogen fertilizer on salinity tolerance of mungbean (Vigna radiate L. Wilczek). J Crop Sci. 61 (3): 439-446.

Laird DA, Fleming PD, Davis DD, Horton R, Wang B, Karlen DL (2010) Impact of biochar amendments on the quality of a typical Midwestern agricultural soil. Geoderma. 158 (3-4): 443-449.

Lehmann J, Joseph S (2009) Biochar for environmental management: an introduction. In: Lehmann, J., Joseph, S. (Eds.), Biochar for Environmental Management: Science and Technology. Earthscan, London, pp. 1-14.

Lehmann JD, Silva JP, Steiner J, Nehls C, Zech T ,Glaser B (2003) Nutrient availability and leaching in an archaeological Anthrosol and a Ferralsol of the Central Amazon basin: fertilizer, manure and charcoal amendments. Plant Soil.249: 343-357.

Leithy S, Gaballah MS, Gomaa AM (2010) Associative impact of bio- and organic fertilizers on geranium plants grown under saline conditions. Electron J Environ Agric Food Chem. 9(3): 617-626.

Lynch DH, Voroney RP, Warman PR (2005) Soil physical properties and organic matter fractions under forages receiving composts, manure or fertilizer. Compost Sei Util. 13: 252-261.
Mansour MMF (2000) Nitrogen containing compounds and adaptation of plants to salinity stress. Biol Plant. 43: 491-500.

Mensah JK, Akomeah PA, Ikhajiagbe B, Ekpekurede EO (2006) Effect of salinity on germination, growth and yield of five groundnut genotypes. Afr J Biotechnol. 5:1973-1979.

Minhas PS, Sharma DR, Singh YP (1995) Response to paddy and wheat to applied gypsum and FYM on an alkali water irrigated soil. J Indian Soc Soil Sci. 43: 452-455.

Muhammad M, Chowdhury MAT, Sarwar I (2007) Floristic condition and species distribution in Sundarban mangrove forest community, Bangladesh. J Bio Sci. 7(2): 384-388.

Nandwal ASM, Godara DV, Kamboj BS, Kundu A, Mann BK, Sharma KP (2000) Nodule functioning in pentafoliate mungbean genotypes as influenced by salinity. Biol Plant. 43: 459-462.

Papadopoulos I, Rending VV, Broadbent FE (1987) Growth, nutrition and water uptake of tomato plants with divided roots growing in differentially salinized soil. Agron J. 77: 2126.

Pessarakli M, Tucker TC (1985) Uptake of nitrogen-15 by cotton under salt stress. Soil Sci Soc Amer J. 49:149-152.

Raafat NZ, Tharwat EER (2011) Improving wheat grain yield and its quality under salinity conditions at a newly reclaimed soil using different organic sources as soil or foliar applications. J Applied Sci Res. 7: 42-55.

Raychev T, Popandova S, Jozefaciuk G, Hajnos M, Sokolowska Z (2001) Physicochemical reclamation of saline soils using coal powder. Int Agrophys. 15: 51.

Sangakkara UR, Hartwig UA, Nosbeger J (1996) Response of root branching and shoot water potentials of French bean (Phaseolus vulgaris L.) of soil moisture and fertilizer potassium. J Agron Crop Sci. 177: 165-173.

Serraj R, Drevon JJ (1988) Effect of salinity and nitrogen source on growth and nitrogen fixation in alfalfa. J Plant Nutr. 21 1805-1818.

Shaon (2016) Growth and yield response of maize to rice husk biochar. An M. S. Thesis, Dept. of Agronomy, Bangabandhu Sheikh Mujibur Rahman Agricultural University, Bangladesh.

Soussi M, Ocana A, Lluch C (1998) Effect of salt stress on growth, photosynthesis and nitrogen fixation in chickpea (Cicerarietinum L.). J Exp Bot. 49: 1329-1337.

StoyanovZZ(2005) Effects of stress on leaf water relation of young bean plants. J Cet Eur Agric. 6(1): 5-14.

Tejada M, Garcia CJ, Gonzalez L, Hernandez MT (2006) Use of organic amendment as a strategy for saline soil remediation: Influence on the physical, chemical and biological properties of soil. Soil Bid Biochem. 38:1413-1421.

Tryon EH (1948) Effect of charcoal on certain physical, chemical and biological properties of forest soils. Ecol Soc Am. 18: 81115.

Verheijen FGA, Jeffery S,Bastos AC, Velde V, Diafas MI (2009) Biochar application to soils-A critical scientific review of effects on soil properties, processes and functions; Office for the Official Publications of the European Communities: Luxembourg. EUR 24099 EN.p: 61.

Wanas SA, Omran WM (2006) Advantages of Applying Various Compost Types to Different Layers of Sandy Soil: 1-Hydrophysical Properties. Appl Sci Res. 2: 1298-1303.

Wardle DA, Zackrisson O, Nilsson MC (1998) The charcoal effect in Boreal forests: mechanisms and ecological consequences. Oecologia. 115:419-426.

Zhang A, Bian R, Pan G, Cui L, Hussain Q, Li L, Zheng J, Zheng J, Zhang X (2012) Effects of biochar amendment on soil quality, crop yield and greenhouse gas emission in a Chinese rice paddy: A field study of 2 consecutive rice growing cycles. Field Crops Resh. 127: 153-160. 